\title{
Research on the Japanese Teaching Reform in the Information Age
}

\author{
Jiqin Wang ${ }^{1}$ \\ ${ }^{1}$ Shandong College of Tourism \& Hospitality, Jinan, Shandong, 250000
}

Keywords: Information Age; Japanese Teaching; Teaching Reform

\begin{abstract}
In the context of the information age, education should pay great attention to the application of information technology so that it can fully play its role in education and improve the effectiveness of education and teaching. However, based on the actual level, it analyzes the actual situation of college Japanese teaching at this stage, determines that the teaching effect is not good, which cannot meet the characteristics of the information age. Based on this, this paper focuses on the analysis of the necessity of Japanese teaching reform under the information age, discusses how to promote the reform of Japanese teaching in the age of informationization, and puts forward feasible opinions, hoping to help improve the level of Japanese teaching in universities.
\end{abstract}

\section{Introduction}

With the arrival of the age of informatization big data, the application of information technology has become more and more extensive and more important. It has played an important role in many fields. Based on this, the field of education in China should correctly recognize the power of science, adhere to the concept of scientific development, effectively apply information technology to education and teaching, make up for the inadequacies of education and teaching at this stage, and promote the development of education in China. In the case of Japanese language teaching, the characteristics of the information age should be clarified. From this point of view, the problems existing in Japanese language teaching should be analyzed in depth. Based on this, it is necessary to explore effective optimization measures and actively promote Japanese language teaching reform. From this perspective, the advancement of Japanese language teaching reform in the information age has a high practical significance [1].

\section{The Necessity of Japanese Teaching Reform in the Information Age}

The policy information on related aspects of Japanese language teaching in our country is understood, and the Ten Year Development Plan for Education Informationization, which was promulgated and implemented in 2012, has set off a wave of education informatization development in the field of education. This is because the overall goal set by the "Plan" is to use a period of ten years to initially build an education information system with Chinese characteristics. The "China Education Informatization Development Report" promulgated and then carried out a comprehensive analysis of the status quo of the development of China's education informatization at the present stage, which fully demonstrates that the current application of information technology in education is not deep enough and will continue in the future. In the process of advancing education, attention should be paid to actively reforming education and teaching, and the characteristics of informatization in education and education should be strengthened so as to promote the sound development of education informatization [2].

With the implementation of policies related to education informatization, we will understand and analyze the actual situation of college Japanese teaching at this stage, and determine that the teaching still adheres to the traditional teaching philosophy and uses traditional teaching methods to develop Japanese language teaching, that is, the process of Japanese teaching. Among them, teachers and textbooks as the center, grammar analysis and translation as means, and reading and translation ability training as the goals, which makes the entire teaching activities carried out, it is difficult to mobilize the subjective initiative of students, resulting in passive learning of Japanese 
knowledge, the mechanized practice of Japanese eventually led to a lack of comprehensive student application skills in Japanese.

The objective analysis of traditional Japanese teaching from a scientific point of view determines that there are many drawbacks, such as excessive emphasis on the learning and use of grammar in the entire teaching process, ignoring the cultivation of students' listening and speaking abilities, and resulting in weaker students' Japanese language communication skills. In the actual conversation process, Japanese cannot be used for effective communication. The Japanese language teaching process is more mechanized. Basically, it is mainly taught by the individual teachers. Students learn passively. During this process, it is difficult for students to obtain speaking opportunities. The corresponding students are difficult to learn. Thinking and practicing Japanese in class can make it difficult for students to improve their level of Japanese. The teaching methods used in Japanese teaching are relatively single, combined with limited teaching conditions, which makes it possible for teachers in the classroom to use only simple model teaching aids. Japanese language teaching is relatively boring, it is difficult to stimulate students' interest in learning, so that students actively participate in Japanese language learning; Teachers have limited time after class, coupled with some students are more timid, it is difficult to communicate well with teachers to solve Learning puzzles or learning Problem, over time, students will be increasing confusion, will eventually lead to students is difficult to accurately understand and master the Japanese language, Japanese students lower level [3].

\section{The Use of Network Resources and the Use of Advantages}

\subsection{Status of Network Resources Utilization}

According to the CNNIC report, the number of online education users in China reached 144 million in 2017, and the number of online mobile education users reached 120 million. The future Internet education users will maintain a rapid growth rate of about $5 \%$. On this basis, further analysis of the actual situation of online language training, to determine the current phase of Internet users to use online language training is about 30\%. This fully demonstrates that language training has become an integral part of online education. Among them, college students who are more receptive to new things are more interested in using computers or mobile phones for online learning. Based on this, network resources will become an important part of education and teaching, and have a greater impact on education and teaching [4].

\subsection{The Advantages of Using Network Resources}

Refer to related materials and summarize the analysis of network resources in our country's education and teaching. The application of actual conditions to determine the advantages of using network resources can be:

First, change the way students learn. With the support of network resources, the learning methods of contemporary college students have changed, from traditional learning methods to mobile learning, that is, college students use mobile phones or tablet computers to learn knowledge anytime anywhere. Compared with traditional learning methods, the effective implementation of mobile learning methods can enhance learners' learning motivation, and can provide learners with many learning opportunities so that learners can use their trivial time to conduct knowledge learning in order to improve themselves. In addition, learners can also set their own learning plan according to their actual situation, and then carry out personalized learning, which is also very helpful for improving students' learning.

The network resources are effectively used in education and teaching. Whether it is the implementation of reversal classrooms or the promotion and application of mumus, all education and teaching are required to be student-centered, teacher-oriented, and based on the actual situation of students, scientific and rational planning of teaching activities. In addition, the application of network resources can also provide a wealth of teaching aids for education and teaching, in order to enrich the teaching content, so as to better teach and train students and improve their knowledge 
level [5].

\section{The Path of Japanese Teaching Reform in the Information Age}

Based on the analysis of the above content, it is determined that the arrival of the information age has made certain changes in the external environment and internal environment of the education field. Under such circumstances, it is necessary to actively promote teaching reforms, realize the development of education and teaching that is advancing with the times, teach and train students well, and enable students to gradually become compound talents that the motherland needs. Based on this, in the face of many deficiencies in college Japanese language teaching at this stage, we should actively promote the Japanese teaching reform from the perspective of the information age. Specific practices include:

To understand the actual situation of enterprises and social workers in China at this stage, to determine the more urgent needs of most Japanese companies in the current stage. This means that Japanese talent must not only possess a high level of professionalism, but also have strong professional skills. Based on this, colleges and universities should clarify the actual situation of social employment, in-depth analysis of the existing problems in Japanese language teaching, and explore effective measures to optimize Japanese language teaching. The author believes that the content of Japanese language teaching should be updated based on information technology. That is, teachers should make clear that the textbooks presented in the Japanese language classroom under the information age have the characteristics of multimedia and resource globalization. On this basis, the scientific and rational analysis of Japanese teaching content deficiencies, such as teaching content is too theoretical, teaching content is lagging, teaching content is biased, etc., and then effectively use network resources to obtain Japanese teaching related materials, combined with the school Teaching characteristics and personnel training plan, scientific and reasonable screening and use of materials, in order to enrich and update teaching content, improve the effectiveness, feasibility and applicability of Japanese language teaching [5].

Whether from the perspective of theory or practice, the level of school teachers has a greater influence on Japanese language teaching. In order to successfully carry out Japanese language teaching activities in the age of information, we should also pay attention to optimizing the construction of teachers. It is to understand and analyze the actual teaching situation of teachers from the perspective of education informationization, and to clarify the deficiencies in teachers and Japanese teaching, such as insisting on traditional concepts, using a single traditional teaching method, and so on. Based on this, we should plan and organize teacher training activities in a scientific and reasonable manner. We should provide pre-training of professional competence, professional quality, information technology, and oral communication skills to teachers, gradually increase the overall level of teachers, and strive to build an excellent teacher team. . In addition, teachers should also be encouraged to watch Japanese news in daily life, participate in Japanese activities, participate in discussion in the Japanese language forum, etc., so that teachers' Japanese language skills, network technology, information technology, etc. can be improved, so that teachers can organize students to carry out informational characteristics [7].

After the analysis of the above content, it is determined that there is still a single teaching method in Japanese language teaching at this stage, which leads to poor teaching of Japanese language and it is difficult to guide students to actively and actively learn Japanese language knowledge so as to gradually increase students' knowledge of Japanese. In order to be able to change this situation, in the context of the information age, reform of Japanese teaching should also pay attention to innovative teaching methods in order to optimize the adjustment of Japanese language teaching and improve the effectiveness and education of the teaching. So how do you do this? First of all, in the process of preparing lessons for Japanese language teaching, teachers should collect materials related to teaching according to the content of the teaching. According to the teaching objectives and the actual situation of the students, they should select suitable materials and apply them to teaching to enrich the teaching contents. On the basis of this, detailed understanding of students' interests, hobbies, personality traits, Japanese knowledge level, Japanese 
communication skills, etc., from the perspective of cultivating students' interest in learning and mobilizing students' subjective initiative to innovate teaching methods, such as multimedia technology, effective Applied to Japanese teaching, it presents three-dimensional and intuitive teaching content, which makes it easier for students to understand abstract Japanese knowledge, effectively learn Japanese language knowledge, and ultimately master Japanese language knowledge. Or, the teaching situation method can be effectively applied to Japanese. In the teaching, it is to create specific scenes or life scenes in the Japanese language class, bring the students into the scene, inspire students' interest in learning, enable students to participate in the Japanese knowledge learning driven by interest, and effectively learn from them [8].

\section{Conclusion}

After a series of analysis of this paper, it is determined that the effectiveness of Japanese language teaching in our university is not good at this stage. The root cause of this is the persistence of traditional teaching concepts, the application of traditional teaching methods to Japanese language teaching, which leads to teacher-centered teaching activities, teaching students theoretical knowledge, and ignoring the mobility of students' subjective initiative. Students' mechanized knowledge in learning Japanese makes it difficult for students to improve their Japanese. This makes Japanese teaching not meet the requirements of China's education policy at this stage. In view of this situation, we should actively promote the reform of Japanese teaching with the information age as updating teaching content based on information technology, innovating teaching methods based on information technology, optimizing the construction of teachers, and so on, which is bound to improve our university.

\section{References}

[1] Liu Jing, Fu Jie. Research on the practice teaching and management of open medical students based on the campus network platform[J]. Journal of Jiangxi University of Traditional Chinese Medicine, 2016, (1):85-86.

[2] Zhang Tian. On the Reform of Japanese Teaching Methods in the Information Age [J]. Popular Literature, 2017, (16): 225.

[3] Guo Shuai. Research on Interactive Japanese Teaching Mode Based on Network Teaching Platform[J]. Heilongjiang Education (Higher Education Research and Evaluation), 2014, (5):34-35.

[4] Yang Jing. Research and Practice of the Construction of Japanese Majors in the View of MOOC [J]. Chinese Market, 2016, (18): 192-193.

[5] Zhang Wei. A Preliminary Exploration of Japanese Teaching Reform in the Information Age [J]. Northern Literature (Last Issue), 2017, (8): 157,159.

[6] Wang Yu. Analysis of Japanese Teaching Reform Based on Information Age Background [J]. Shenzhou, 2017, (5): 69.

[7] Wang Yu. Analysis of Japanese Teaching Reform Based on the Information Age [J]. Shenzhou (Chinese Journal), 2017, (2): 69.

[8] Liu Yuxia. Analysis of the Development Trend of Japanese Teaching in Colleges and Universities under the Background of Globalization[J]. Culture and Education Data, 2013(21):50-51. 